\title{
THE MEANING OF THE IMMOVABLE GOODS SALE UNDER THE CURATOR'S HANDS
}

\author{
Dr. Ivida Dewi Amrih Suci, S.H., M.H. \\ Prof. Dr. M. Khoidin, S.H., M.Hum, C.N. \\ Prof. Dr. Herowati Poesoko, S.H., M.H. \\ Dr. Dyah Ochtorina Susanti, S.H., M.Hum. \\ Dr. M. Hadi Shubhan, S.H., M.H. \\ Dr. Aries Harianto, S.H., M.H \\ Dr. Moch. Ali, S.H., M.H. \\ Notary Study Program, Postgraduate of Faculty of Law, University of Jember
}

\begin{abstract}
The verdict of bankruptcy statements against debtors change the legal status of a person to be incapable of carrying out legal actions. All arrangements and settlement of bankrupt debtor assets are carried out by the curator. One way of selling bankrupt assets is by selling under the hands of the curator with the permission of the supervisory judge. However, the Law does not explain what is meant by types of objects, especially immovable objects and the sale process under the hands of the supervisory judge's permission clearly and firmly. For these factds, this study aims at analyzing and finding the meaning of immovable objects sale under the hands of the curator. For this analysis, it uses such approaches as statute approach, conseptual approach, and case approach. The research result found out the concept that the immovable objects according to the type in guarantee law can be qualified as land. The sale of immovable objects on bankrupt assets under the hands of the curator if the ownership rights in the debtor's name only require the supervisor's permission. However, if the bankrupt assets which ownership rights are in the name of a third party, the supervisory judge's permission is used to submit a request to the Commercial Court to determine the authority of the curator to sell immovable objects under the hand. The curator is responsible for errors and / or negligence in carrying out the management duties and / or settelement that causes losses to bankrupt assets, both in civil law and criminal law.
\end{abstract}

Keywords: civil law and criminal law, bankrupt, immovable goods.

DOI: $10.7176 / J L P G / 87-21$

Publication date:July $31^{\text {st }} 2019$

\section{Preliminary}

In the context of creating a just and prosperous society based on Pancasila and the 1945 Constitution of the Republic of Indonesia, the development of national law is directed at the realization of a national legal system with the formation of new laws needed to support the development of the national economy. ${ }^{1}$ One of the efforts to settle accounts payable is the decision of a bankrupt statement, which can change the legal status of a person to be incapable of carrying out legal actions, control and manage his assets since the decision on a bankrupt statement was pronounced. ${ }^{2}$ This is needed for people / legal entities who feel that their interests are disadvantaged. When a person / legal object is declared bankrupt, the bankrupt assets or bankrupt objects are divided equally among the creditors in prorate parte. ${ }^{3}$ In the general confiscation of all the assets of the bankrupt debtor, the management and settlement is carried out by the curator under the supervision of the supervisory judge. This is to fulfill the achievement when the debtor is unable to make payments on the debts of his creditors regulated in Law Number 37 of 2004 concerning Bankruptcy and Delay of Obligations of Debt Payment (hereinafter abbreviated as UUK) governing the definition of bankruptcy of a person or entity law regulated in Article 1 paragraph (1).

As a basis for the implementation of bankruptcy law there are several principles, including the principles of balance, the principle of business continuity, the principle of justice and the principle of integration. As a result of bankruptcy, besides having an impact on the rights and obligations of the bankrupt party (bankrupt debtor), it also has an impact on the rights and obligations of others as the party providing loans for their business (other creditors). How to bankrupt someone or a legal entity seems very easy. If the debtor's assets are far above the debt value provided that there are two or more creditors even though one of them is not paid in full, while the other has matured, then the debtor can be very easily declared bankrupt as referred to in Article 2 paragraph (1). In selling bankrupt assets to pay creditors' bills to be resolved immediately is the authority of the

\footnotetext{
Ivida Dewi Amrih Suci, Karakteristik Hukum Acara Renvoi Prosedur Dalam Perkara Kepailitan, Disertation, Doctoral Program of Legal Science, Post-graduate Program, Faculty of Law, University of Jember, unpublished, Jember, 2018 p. 1

2 Munir Fuady, Hukum Pailit dalam Teori dan Praktek, Bandung: Citra Aditya Bakthi, 2014, pp. 328-329

3 Ivida Dewi Amrih Suci I, Op.Cit, p.1
} 
curator. The process of selling bankruptcy by the curator is 3 (three) ways, among others: first based on Article 184 paragraph (1) UUK, the commencement of bankruptcy assets is without having to obtain bankruptcy debtor's approval of all bankrupt objects with public sales; second based on article 185 paragraph (1) UUK, sale is performed by the curator to all objects without distinguishing the type and type of the object; third, based on Article 185 paragraph (2) UUK, if there is no public sale at auction, the curator can sell under the hand with the permission of the supervisory judge.

Based on the regulation on the process of selling the bankrupt assets mentioned above, only 2 (two) things need to be observed in Article 185 paragraph (1) of the Law, which does not explain the type or type of the item. If seen in the legal system, objects according to BW include movable and immovable objects; tangible and intangible objects, moreover an object which has the privilege certainly has different Institution to guarantee and how to sell it. Likewise, Article 185 paragraph (2) UUK emphasizes that if the sale of bankrupt objects does not reach public sales at auction, the curator can sell under the hand with the permission of the supervisory judge. Understanding the article is vage norm. Also considering the existence of Decision Number 09 / Other Claims / 2013 / PN.NIAGA. JKT. PST Jo. No. 28 / PKPU / 2011 / PN.Niaga.Jkt.Pst. September 25, 2013 with the subject matter of the permission of the supervisory judge, and Decision $556 \mathrm{~K} / \mathrm{Pdt}$.Sus-Pailit / 2013 dated January 22, 2014, in fact the authority of the curator and / or the settlement of bankrupt assets has caused losses to the parties due to the sale of immovable property under the hand.

On the basis of these thoughts and considerations, the researcher found a legal issue about the meaning of selling immovable objects under the hands of the Curator. In connection with that, the problem was formulated as in the question "What is the meaning of the sale of immovable objects under the hand of the curator in the permission of the supervisory judge?"

\section{Research Methods}

Research is a basic tool in the development of science and technology, in search of truth systematically, logically, methodologically and consistently, including legal research. ${ }^{1}$ Legal research is carried out with the distinctive character of legal science (jurisprudence) which is different from social science or natural sciences. ${ }^{2}$ Legal science is sui generis ${ }^{3}$ which means that law is a science that has its own type (suum: itself; genus: type) in the sense that legal science cannot be grouped in one branch of the tree of science. The distinctive feature of legal science is normative science. ${ }^{4}$ A process for finding legal rules, legal principles and legal doctrines to answer the legal issues at hand ${ }^{5}$ Legal research is conducted to produce new arguments, theories or concepts as prescriptions in solving problems that occur or are prescriptions of answers to legal issues raised by the researchers. ${ }^{6}$

There are four approaches used in this study, namely statute approach, conceptual approach, historical approach to the enactment of legislation (rechts historical approach), and case approach carried out by reviewing all laws and all regulations concerned with legal issues that they wish to answer. This is done to explore consistency and conformity between laws and regulations including between the Basic Laws, between regulations and various laws and regulations. ${ }^{7}$ In turn, it produces prescriptions in order to make revisions or improvements in creating new legal products.

\section{Results and Discussion}

These results and discussions will analyze the problem described above, so to be coherent this discussion will describe one by one the issue with the following results:

This study is a legal study in the realm of bankruptcy law. To answer legal issues in this study, the author's flow of thought starts from examining and analyzing the concept of immovable objects on the types, properties, and principles of immovable objects on their material rights. So that it can identify and qualify for immovable objects in order to find the concept; second, regarding the sale of immovable property of bankrupt assets under the hands of the curator; third, the curator's sales conditions for immovable objects with the permission of the supervisory judge. For types of immovable property, the nature of material rights and the principle of immovable objects so that they can identify, structure immovable objects in order to find the concept of immovable objects. Broadly speaking, the types of objects known in BW are as follows: tangible and

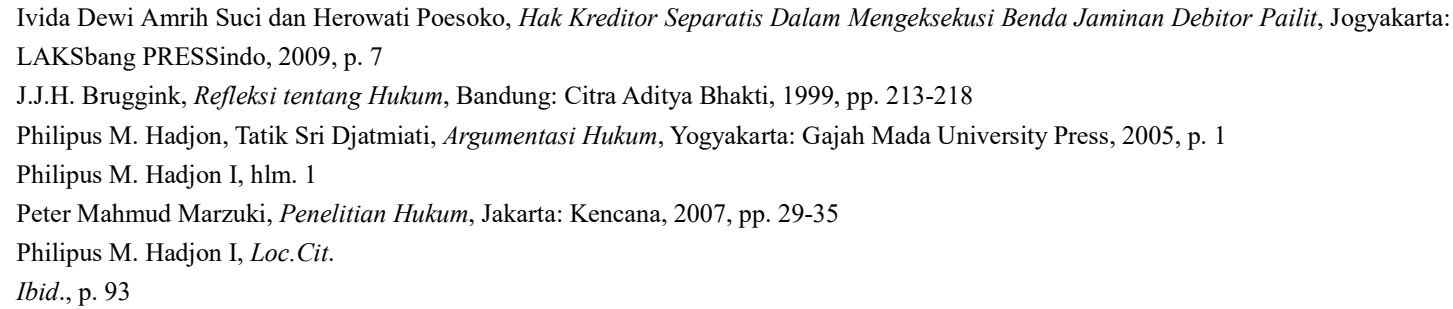


intangible objects (lichamalijke zaken - onlichamelijke zaken, Article $503 \mathrm{BW}$ ); movable and immovable objects (roerende zaken - onroerende zaken, Article $504 \mathrm{BW}$ ); objects which are used up and objects which are not used up (verbruikbare zaken - onverbruikbare zaken, Article $505 \mathrm{BW}$ ); objects in trade and objects outside of trade (zaken in de handle - zaken buiten de handle, Article $1332 \mathrm{BW}$ ); existing objects and objects that will exist (toekomstige zaken - tegenwoordige zaken, Article $1334 \mathrm{BW}$ ); objects that can be divided and objects cannot be divided (deelbare zaken - ondeelbare zaken, Article 1163); replaceable objects and non-replaceable objects (vervangbare zaken - onvervangbare zaken, Article 1694).

Regarding immovable objects there is an important development because there are changes based on laws and regulations. Historically moving objects cannot be separated from the legal system of objects in Book II BW. The land that was originally entered into immovable objects but with the existence of Law Number 5 of 1960 concerning Basic Regulations on Agrarian Principles (hereinafter abbreviated as UUPA), which adheres to adhering to a horizontal system, while BW adheres to a vertical system, becomes a moving object. All regulations concerning material rights (zakenrecht) relating to the earth, water and natural resources contained in them contained in this Book II become invalid, except for some regulations concerning mortgages other than land.

Juridically objects are anything that can be an object of ownership, also known as the subject of rights and objects of rights. The object of rights in the form of objects, especially immovable objects, has the nature of material rights, among others, absolute (absolute), which means that they can be maintained and protected from any interference from third parties; having the nature of following the object (droit de suite) it can be exemplified that the lease agreement does not break up because it is moved or sold for goods leased; priority is the right that takes precedence (preference). As for the type of collateral used for movable objects it is in the form of pawn, while for immovable objects it is mortgage, but in its development with the emergence of Law Number 5 of 1960 concerning Basic Regulations on Agrarian Principles (hereinafter referred to as UUPA), especially concerning land it can be guaranteed by Mortgage right. Every immovable object is material right, that is, the absolute right of an object where that right gives direct power over something and can be defended against anyone. If seen from the position, the material rights which is in the rights of individuals (persoonrecht) which have the characteristics/characteristics of material rights is an absolute right, which means that it can be defended against anyone, has the right zaakgevolg or droit de suit (rights that follow).

In business practice, objects that are objects of guarantee are movable and immovable objects, because that is also known as the guarantee of movable and immovable objects. Likewise in banking practices, to further secure the funds distributed by creditors to debtors needs additional safeguards in the form of special guarantees that are widely used and needed as collateral in the form of land. The use of land as collateral for credit, both for productive credit and consumptive, is based on the consideration of the safest land and has a relatively high economic value. ${ }^{2}$ The economic value that is intended can be transferred, guaranteed or transferred by the owner of the material rights. When viewed from the nature and character or characteristics, immovable objects can be qualified with material guarantee rights in the form of land. Initially this was guaranteed as mortgages, but after Law No. 4 of 1996 concerning the Right to Underwrite Land and Objects Related to Land (hereinafter abbreviated as UUHT) became the basis of collateral in the form of land, if qualified by principle, its character, in accordance with immovable object. Therefore it can be understood that immovable objects are identical to land.

Analyzing the sale of immovable objects under the hands of the curator is done by structuring and using legal construction to find the right basis in its implementation because it is not regulated by the Law. Based on Article 185 paragraph (2) UUK, the curator has the authority to be able to carry out sales under the hand with the permission of the supervisory judge if public sales are not acceptable. The article provides an interpretation that the supervisory judge has the authority to give permission in the transition of bankrupt objects, both movable and immovable. This study is focused on immovable objects which became bankrupt objects with the permission of the supervisory judge. The supervisory judge's permission is not the same as the determination of the supervisory judge. The supervisory judge is not authorized to make a determination, in other words Permission is not a stipulation.

The determination is owned by the judge of the commercial court obtained from the permission given by the supervisory judge. A curator has a fairly heavy duty in carrying out the management and bankruptcy of assets, ${ }^{3}$ because all legal actions that have been carried out by the curator in carrying out the management and bankruptcy of assets cannot be restored to their original state and are binding on all parties, ${ }^{4}$ it is even possible

\footnotetext{
M. Isnaeni, Benda Terdaftar Dalam Kontelasi Hukum Indonesia, Jurnal Hukum, No. 13 Vol. 7 April 2000, p. 52

2 Agus Yudha Hernoko, Lembaga Jaminan Hak Tanggungan Sebagai Penunjang Kegiatan Perkreditas Perbankan Nasional, Tesis, Pascasarjana UNAIR, Surabaya, 1998, p. 7

3 Ivida Dewi Amrih Suci dan Herowati dalam Disertasi Hukum Acara Renvoi Prosedur Dalam Perkara Kepailitan

$4 \quad$ Ibid, p.246.
} 
for many obstacles to occur. The authority of the Curator in the case of the sale of immovable property under the hands of the supervisory judge's permission, covering immovable objects according to BW II book, including mortgage and mortgage as material rights which in principle follows a closed system. It means that the curator of his authority can make a sale, so that it does not involve the debtor. Even the curator gets juridical authority in Article 69 Paragraph (2) of UUK. ${ }^{1}$

Bankruptcy law has a limitative element to objects which are not included in UUK bankruptcy, giving two concepts of bankrupt asset sales, namely sales in public and sales under the hand. Public sales carried out by the curator are included in the realm of bankruptcy procedure in this case lex specialis or special and exceptional. ${ }^{2}$ Public sales are normally carried out through the Auction Center, based on the Auction Rules, Sales Regulations in public in Indonesia (Ordinance 28 February 1908, S. 1908-189, effective from 1 April 1908) (S. 1940-56 jo S. 1941 -3, article 1 This regulation has been replaced by Article 1, He, Lb.) ${ }^{3}$ Furthermore, the Regulation of the Minister of Finance of the Republic of Indonesia Number 13 / PMK.06 / 2018 concerning Auction of Confiscated Items, Goods Confiscated by the State, or Objects of Execution from the Indonesian Prosecutor's Office, Article 1 number 1 states that "Auction is the sale of goods open to the public written and / or verbal price quotes that are increasing or decreasing to reach the highest price, which is preceded by an Auction Announcement. Next is the execution auction process which is an auction to carry out a court ruling or stipulation, other documents that are equivalent to it, and / or implement the provisions in the legislation" 4 Furthermore, considering the auction activities with the permission of the supervisory judge, it is necessary to review the sale of immovable objects by the curator under the hand. The auction activity is a legal act carried out by parties that bind themselves and in it there are elements of bargaining or bidding. Therefore, the consensus of buying and selling publicly on immovable objects (bankrupt objects) is based on the price agreed upon by the curator who acts as the auction participant, so that it reaches the implementation of the sale of bankrupt objects in public based on Permenkeu R.I. No. 13 / PMK.06 / 2018.

The sale of bankrupt objects by the curator in the form of immovable objects under the hands of which is only authorized by the Supervisory Judge is an ambiguous regulation. On the one hand, the procedure is not regulated. On the other hand the ownership of sales of immovable objects is not necessarily the certificate in the name of the debtor itself. The sale of immovable objects is the transfer of rights from subject to subject to another that requires legal certainty to bind the parties and protect the buyer under the hand. The under-hand sales of immovable property due to UUK defaults do not regulate clearly, but in Article 20 paragraph (2) and (3) UUHT is stated:

(1) Based on the agreement of the giver and the holder of the Underwriting Right, the sale of the Underwriting Right object can be carried out under the hand if thus the highest price can be obtained that benefits all parties.

(2) The sales implementation as referred to in paragraph (2) can only be carried out after a period of 1 (one) month from the written notice by the giver and / or the Underwriting Right Holder to the interested parties

$1 \quad$ Article 69 paragraph (2) section a and b state :

a. Not required to obtain approval from or to give prior notification to the debtor or one of the debtor's organs, even if such conditions outside the bankruptcy agreement or notification are required;

b. Making loans from third parties, only in order to increase the value of bankrupt assets.

2 Article 171 Faillissment Verordening states that:

(1) All goods must be sold in public or with the permission of the commissioner judge, sales can also be carried out under the hands. (F. 98);

(2) Regarding all goods which cannot be immediately or completely unable to be cleared, the Heritage Hall shall make a decision in a manner authorized by the Supervisory Judge. (F. 66);

(3) With regard to the goods upon which detention rights can be exercised by creditors, the Heritage Property shall return it to bankrupt assets, by paying the accounts receivable in question, if such matters benefit the bankrupt assets. (F. 59, 231).

3 Article 1. The application of this regulation is from implementing regulations that have been and will be determined based on this regulation, what is meant by "General Sales" (openbare verkopingen) is the auction or sale of goods carried out to the public by offering prices that increase or decrease or are previously notified of the auction or sale, or are allowed to participate, and are given the opportunity to bid interest, agree on the price offered or enter the price in a closed cover. (Vendu-regl. Ib, 84.5)

${ }^{4}$ Regulation of the Minister of Finance of the Republic of Indonesia Number 13 / PMK.06 / 2018 concerning Auction for Confiscated Items, Goods Confiscated by the State, or Objects of Seizure Execution originating from the Prosecutor's Office of the Republic of Indonesia 
and announced at least in 2 (two) newspapers circulating in the area concerned and / or local mass media, as well as no party expressing objection.

So that if the curator through his authority, if in the certificate of ownership in the name of the debtor itself, can use the procedure under the hands in accordance with Article 20 paragraph (3) UUHT. However Article 185 paragraph (2) of the Law does not require if the certificate of ownership rights in his name is written by the third party owner of immovable property to attend the sale under the hand or there is no provision that there is a power to sell.

According to the researcher, if it is stated on the ownership rights or the third party then the seller requires a special power of attorney to be present at the sale under the hand and there is no provision that there is a power to sell. The third party to the curator who has obtained a stipulation from the Commercial Court to sell under the hands of immovable objects, especially land whose substance is related to the object to be sold, including offering, receiving money from the sale as a whole up to the process of transferring rights, binding to the parties both buyers and sellers and related third parties. The permission of the supervisory judge is to request a judgment from the court if the owner of the object is not willing to sell (does not come), requesting power of attorney to the land owner on behalf of a third party.

According to the author, the use of the special power of attorney is from the bankrupt debtor over the third party to the curator, who only specifically sells immovable objects under the hand at auction. The use of the special power of attorney is to strengthen and bind and is legal according to the law of the transfer of rights between the parties, the seller (curator) with the buyer and the BPN. To assess the meaning of the supervisory judge's permission as a requirement for the sale of immovable objects under the hands of the curator in terms of theory and practice by analyzing 2 (two) decisions of the Supreme Court covers:

a. The verdict of the Supreme Court of the Republic of Indonesia No. 556 K / Pdt.Sus-Pailit / 2013, January 22, 2014.

b. Decision Number 09 / Other Claims / 2013 / PN.NIAGA Jkt.Pst Jo Number 28 / PKPU / 2011 /

PN.Niaga.Jkt.Pst., October 2, 2013

\section{A. Legal Considerations (Ratio Desidendi) Decision of the Supreme Court of the Republic of Indonesia Number: 556 K / Pdt.Sus-Pailit / 2013, January 22, 2014}

This decision is a verdict on the case between PT Nur Jaya Sukses and the Curator of PT Nur Jaya Sukses. In this case, PT Nur Jaya Sukses submitted a request for cancellation of the Judge's Determination in a bankruptcy case before the Commercial Court trial at the Central Jakarta District Court. This application is based on the Decision of the Commercial Court in the Central Jakarta District Court Number: 44 / PKPU / 2012 / PN.Niaga. Jkt. Pst., December 26, 2012, which stated that PT Nur Jaya was Successful in Bankruptcy. This decision has also been submitted for cassation at the Supreme Court of the Republic of Indonesia on December 27, 2012. During the process of examining the cassation, the curator has made several offers to sell bankrupt assets belonging to the bankrupt debtor / PT. Jaya Nur Sukses through the Jakarta Wealth Service Office and Jakarta IV Auction based on Determination of Supervisory Judge Number: 44 / PKPU / 2012 / PN.Niaga.Jkt.Pst., April 1, 2013. The Supervisory Judge who issued and signed the Determination was AGUS ISKANDAR, S.H., M.H. But Commerce Judge Supervisory Certification AGUS ISKANDAR, SH, MH, by the Supreme Court of the Republic of Indonesia has been revoked as a Commercial Judge and commenced on May 21, 2013 and then as the Judge Supervisor of the Case Decision Number: 44 / PKPU / 2012 / PN.Niaga.Jkt. Pst., Since 26 December 2012 was replaced and stipulated: KASIANUS TELAUMBANUA, SH, MH. Therefore, according to the applicant for legal cassation Determination Number: 44 / PKPU / 2012 / PN.Niaga.Jkt.st., Dated April 1, 2013 signed by AGUS ISKANDAR, S.H., M.H. As of May 21, 2013, it has ended and has fallen and has no legal force.

If it is analyzed according to the establishment of the Law concerning the request for cassation, the provisions of Article 185 paragraph (2) of Law No. 37 of 2004 can only be implemented if the provisions of Article 185 paragraph (1) of Law No. 37 of 2004 has been fulfilled and not achieved. For this reason, the provisions of the sale under the hand are regulated separately which can be done with the permission of the Supervisory Judge based on the provisions of Article 185 paragraph (2) of Law No. 37 of 2004. Thus the incorporation of the provisions of Article 185 paragraph (1) of Law No. 37 of 2004 with the provisions of Article 185 paragraph (2) of Law No. 37 of 2004 into 1 (one) Determination No. 44 / PKPU / 2012 / PN.Niaga.Jkt.Pst., April 1, 2013 is contrary to law or legal defect. Therefore the applicant for cassation requested the determination to be canceled.

The reason of the cassation applicant in the cassation memory is based on such evidence as where as the assessment of proof is an appreciation of something reality that cannot be considered in the examination at the appellate level, because the examination in the cassation level only concerns the error of the application of the law; The violation of applicable law or negligence in fulfilling the conditions required by legislation that 
threatens the violation with the cancellation of the decision, or if the judge is not authorized or exceeds the authority limit as intended in Article 30 of Law No. 14 of 1985 as amended by Act No. 5 of 2004 and the second amendment to Law No. 3 of 2009 and other legislation concerned. On the basis of the above facts, the Supreme Court with its decidend ratio has rejected the appeal request of PT Nur Jaya Sukses.

According to the researcher, the applicant should appeal the reason that the curator likens the permission of the supervisory judge to the stipulation. According to legal science, the position of permit is not the same as stipulation. If based on Article 185 paragraph (1) of UUK, it is indeed quite permissible from the supervisory judge because the process carried out is in accordance with the Law. Hoewever, when Article 185 paragraph (2) UUK is different in meaning, the permit of the supervisory judge is not a stipulation, but the permit is to ask the judge of the commercial court for decision of being eable to sell the immovable objects under the hands, if the owner of the immovable object is not a debtor. This is also corroborated in Article 69 UUK, which in essence the curator can sell bankruptcy assets in accordance with Article 185 paragraph (1) UUK or in accordance with Article 185 paragraph (2) UUK under the hand.

Bankrupt assets that do not belong to the debtor but include bankrupt assets must still be through the permission of the supervisory judge. However, the permit application is to submit a determination to sell bankrupt assets which are held in the name of a third party. Therefore the permit of the supervisory judge is not a stipulation because the determination is the authority of the judge of the commercial court.

\section{B. The Verdict Number 09 / Other Claims / 2013 / PN. NIAGA Jkt.Pst Jo Number 28 / PKPU / 2011 / PN.Niaga.Jkt.Pst. Dated 2 October 2013}

The case in this verdict was between the Curatorial Team of PT Mitra Safir Sejahtera (in bankruptcy) against several creditors who were referred to as Defendants I to Defendant XI. In essence, the lawsuit of PT. Mitra Safir Sejahtera consists of exceptions, revisions and subject matter. The background of the plaintiff's claim to the plaintiffs was due to the action of Defendant I until the defendant XI filed a lawsuit toderail the auction of the bankruptcy process of PT Mitra Safir Sejahtera (in bankruptcy) so that there was no transfer of PT Bank Safir Sejahtera's bankrupt assets by the curator though the bankruptcy condition of PT Mitra Safir Sejahtera (in bankruptcy) in the case of an incident is considered as a violation of the law and may harm the bankrupt bankruptcy as stated in the case decision Number 09 / Other Lawsuit / 2013 / PN. NIAGA Jkt.Pst Jo Number 28 / PKPU / 2011 / PN.Niaga.Jkt.Pst. Dated October 2, 2013.

The legal consideration is that the Commercial Court judge at the Central Jakarta District Court has no authority to accept and try this case (absolute competence). The Panel of Judges is of the opinion that the Commercial Court is not authorized to accept and adjudicate the a quo case, thus the exception of the Plaintiff to absolute competence is acceptable. Considering that the exception of absolute competence is granted then another exception does not need to be considered again and the Commercial Court at the Central Jakarta District Court must declare that it is not authorized to examine and try the a quo case. When viewed from the main conditions, the auction is to gather interested parties to enter into the most profitable sale and purchase agreement with the seller with the conditions that the general seller must be as complete as possible, there is a will to bind themselves, the party who will enter into an agreement cannot be appointed, with In other words, there has been no violation of the auction rules if it only gives an opportunity to the public to make an offer. ${ }^{1}$ The elements in those requirements are guidelines for general auction implementation.

The bankruptcy process involves a new legal institution that is not known in civil law events and even in other procedural law, namely the presence of supervisory judges. Even though this institution is exclusive, its provisions are not new in bankruptcy law, because it has existed since the Dutch-era bankruptcy rules known as commissioner judges. The duty and authority of the supervisory judge oversees the management and bankruptcy of assets. ${ }^{2}$ The juridical affirmation of the supervisory judge, in Article 1 number 8 UUK is a judge appointed by the Court in a bankrupt decision or a decision to postpone debt repayment obligations. It means that the supervisory judge is the judge who is authorized by the Commercial Court within the scope of the General Court, to oversee the management and bankruptcy of the assets.

Vague norms in the meaning must be understood in advance the duties and authority of the supervisory judge and the judges of the commercial court in bankruptcy law. In the previous sub-chapter, it has discussed the difference between assignments of authority between supervisory judges as supervisors in the management and / or bankruptcy of assets by the curator. In carrying out the duties, the supervisory judge only has administrative authority by giving licenses or every oversight of the management and / or bankruptcy of assets, the supervisory judge does not have the right to examine cases containing or will contain the dispute until deciding on a good case in the form of stipulation or in the form of a decision. The task of the panel of judges' authority in

\footnotetext{
Ibid. p.34

M.Hadi Shubhan,Op.Cit. pp.104-105
} 
bankruptcy law is the same as that of the assembly in other cases, namely examining and deciding the case that ends with a decision or determination. One of the uniqueness of bankruptcy law which is a lex specialis in civil law is the purpose of bankruptcy procedural law that deviates from its principle, namely the purpose of the form of submission in the form of an application (request) and finally a verdict (vonnis). This is because the material submitted is very simple, namely the conditions based on Article 2 paragraph (1) of the Bankruptcy Law, which stipulates that "Debtors have two or more creditors and one of the debts is due, the judge can bankrupt". ${ }^{1}$

On this basis, everyone can make a bankrupt application, but if the final examination is in accordance with the principle, namely the determination (daagwarding) that applies only to the applicant. Then bankruptcy based on Article 1 paragraph (1) UUK is a general seizure that applies to all people related to the case even if they do not participate in submitting an application. Therefore a verdict is needed (vonnis), so that the examination finally makes a punishment that binds all parties. The deviation is carried out as in the procedural law in filing for divorce or enforcement of legal principles in the procedural law of the State administrative court. $^{2}$

The results of the analysis above there are differences between the meaning of "permission" and "determination". Therefore, when the Law regulates "permission of the supervisory judge" does not mean as "the determination of the supervisory judge". The error of reasoning carried out by the curator in translating article 185 paragraph (2) of the UUK creates an error in the implementation of the management and / or deposit of bankrupt assets. This can lead to injustice both against bankrupt debtors and creditors or other related parties, because curators can arbitrarily determine prices and so on. With the permission of the supervisory judge, the curator should still process by requesting a determination request to the commercial court to determine the sale under the hand to be carried out, as well as fixing the price, as well as the request for auction determination. This is also because the meaning of the supervisory judge's permission is not the appointment of the supervisory judge, so that the contents of article 185 paragraph (2) of the Law do not explicitly regulate so that it is not legal certainty and vague norms.

The negligence of the interpretation carried out by the curator on article 185 paragraph (2) UUK that is vague (vague norm) and has no legal certainty in the law can cause injustice to the parties concerned. If this happens, the article must be corrected first. This can be done through a request for a judicial review of the article to the Constitutional Court by correcting the meaning, the institution, and the loss of the parties referred to in the article by basing on several decisions as the actuality. Therefore, in managing and / or settling bankrupt assets, the curator must be careful and continue to hold the principle of legal certainty in interpreting each article, because the management and bankruptcy of assets is included in civil procedural law even though there are procedural laws in the bankruptcy law itself.However, the principle of procedural law which is $d$ wingend recht must be taken into account, because the bankruptcy law signs in the procedural law also refer to the HIR / Rbg.

The curator's actions in the management and / or bankruptcy of assets are very extensive on bankrupt assets. Not only that, the curator can take hostage against bankrupt debtors in accordance with article 31 paragraph (1) of the Law. It is not possible that the curator will commit an illegal act or even a criminal act. If the curator's actions are related to criminal acts, that is, one example of taking goods that are not bankrupt assets, the curator can be reported as a criminal act. If the curator commits a violation of the law by harming the bankrupt assets resulting in a loss to the bankrupt debtor or the creditor, the bankrupt debtor or the creditor can submit an application to the panel of judges to request the replacement of the curator. If the loss is due to a criminal act, they can report the curator's actions to the authorities. If the curator's actions in the framework of the management and / or bankruptcy of assets have errors, articles 16 paragraph (2) and article 17 UUK can also be applied. So in the analysis of these two articles, the steps of the curator in all arrangements and / or mass bankruptcy are protected. Article 16 paragraph (2) UUK states as follows:

In case that the decision on bankruptcy is canceled as the result of cassation or review, all actions that have been carried out by the curator before or on the notice of the curator's receiving a notification regarding the cancellation decision referred to in article 17 remains valid and binding on the debtor. Article 17 of the Law intended by article 16 paragraph (2) of the Law is stated as follows:

(1). The curator must announce the cassation verdict or review which invalidates the bankrupt decision in the State Gazette of the Republic of Indonesia and at least 2 (two) daily newspapers as referred to in article 15 paragraph (4).

(2). The panel of judges who cancels the decision on the bankrupt statement also stipulates bankruptcy fees and compensation for curator services.

(3). Fees as referred to in paragraph (2) are charged to the applicant for bankruptcy statements or to the applicant and debtor in the competition determined by the panel of judges.

Ivida Dewi Amrih Suci, Disertasi, Ibid, p. 132

Ibid. 
(4). For the implementation of payment of bankruptcy fees and compensation for curator services as referred to in paragraph (2) the Chairperson of the Court issues the determination of execution at the request of the curator.

(5). In the case of the decision to cancel the bankruptcy statement, the peace that may occur is due to the law.

In addition to the above article, there are regulations which limit the movement of the curator, but limited to the loss of bankrupt assets. Toward the losses of the parties, the bankruptcy law does not regulate it. This arrangement is in article 72 UUK which states as followsl: The curator is responsible for mistakes and negligence in carrying out the management duties and / or eradication that causes losses to bankrupt assets. The results of the discussion above show that the curator is only responsible for the loss of bankrupt assets, if the injured party is not regulated in depth in the Law. Because the law integrates intact with BW and also in its procedural law also integrates intact with the HIR / Rbg, if there are losses to the parties as a result of the curator's actions, the two Laws apply. If it is related to criminal law, then Criminal Law will also apply.

\section{Conclusion}

Based on the result of the research, it can be concluded as follows The concept of immovable property according to type in the guarantee law can be qualified as land. The sale of immovable property on bankrupt assets under the hands of the curator if the ownership rights in the debtor's name only requires the supervisor's permission. However, if the bankruptcy rights of ownership rights are in the name of a third party, the supervisory judge's permission is used to submit a request to the Commercial Court to determine the authority of the curator to sell immovable objects under the hand. The curator is responsible for errors and / or negligence in carrying out the management duties and / or settlement that causes losses to bankrupt assets, both in civil law and criminal law.

\section{Suggestion}

Based on the above conclusions, shows that there are still weaknesses normatively related to the impose of verstek verdict and its legal efforts, therefore the author suggests several things, as follows:

1. There should be a strict regulation of land before the exisence of the legal system of objects nationally that the type of immovable object is land.

2. There should be a strict regulation regarding the permit of the supervisory judge so that it is not equated with the stipulation of the Commercial Court, especially for the sale of immovable property whose ownership is in the name of a third party.

3. Reminding the curator that for his errors and omissions, that for the sale of immovable property under the hands of those who have ownership rights on behalf of third parties may enter the realm of civil law and criminal law.

4. There should be a strict and clear regulation regarding the sale of immovable property underground which is owned by the curator in the name of a third party.

\section{References}

\section{A. Books}

Ivida Dewi Amrih Suci dan Herowati Poesoko, Hak Kreditor Separatis Dalam Mengeksekusi Benda Jaminan Debitor Pailit, Jogyakarta: LAKSbang PRESSindo, 2009.

J.J.H. Bruggink, Refleksi tentang Hukum, Bandung: Citra Aditya Bhakti, 1999.

Munir Fuady, Hukum Pailit dalam Teori dan Praktek, Bandung: Citra Aditya Bakthi, 2014.

M. Isnaeni, Benda Terdaftar Dalam Kontelasi Hukum Indonesia, Jurnal Hukum, No. 13 Vol. 7 April 2000.

Peter Mahmud Marzuki, Penelitian Hukum, Jakarta: Kencana, 2007.

Philipus M. Hadjon, Tatik Sri Djatmiati, Argumentasi Hukum, Yogyakarta: Gajah Mada University Press, 2005.

\section{B. Journal/Scientific work/Disertation}

Agus Yudha Hernoko, Lembaga Jaminan Hak Tanggungan Sebagai Penunjang Kegiatan Perkreditas Perbankan Nasional, Tesis, Pascasarjana UNAIR, Surabaya, 1998.

Ivida Dewi Amrih Suci, Karakteristik Hukum Acara Renvoi Prosedur Dalam Perkara Kepailitan, Disertasi, Program Doktor Ilmu Hukum, Program Pascasarjana, Fakultas Hukum Universitas Jember, tidak dipublikasikan, Jember, 2018.

M. Isnaeni, Benda Terdaftar Dalam Kontelasi Hukum Indonesia, Jurnal Hukum, No. 13 Vol. 7 April 2000, 


\section{Legislations}

\section{Burgerlijek Wetboek}

Law Number 37 of 2004 concerning Bankruptcy and Postponement of Obligations of Debt Payments

Law Number 5 of 1960 concerning Regulation of Basic Agrarian Principles

Law Number 4 of 1996 concerning the Right to Underwrite Land and Objects Related to Land

Regulation of the Minister of Finance of the Republic of Indonesia Number 13 / PMK.06 / 2018 concerning Auction for Confiscated Items, Goods Confiscated by the State, or Objects of Seizure Execution originating from the Prosecutor's Office of the Republic of Indonesia 